\title{
Effect of Spacing on Growth Attributes and Socio-economic Benefits of Marigold (Tagetes species) under Subabul (Leucaena leucocephala) based Agroforestry System
}

\author{
Swati Suchi* \\ School of Forestry and Environment, Sam Higginbottom Institute of Agriculture, Technology \\ \& Sciences, Allahabad (Uttar Pradesh) 211007, India \\ *Corresponding author
}

A B S T R A C T

\section{Keywords}

Tagetes erecta, Tagetes patula, Agroforestry,

Leucaena leucocephala, Spacing, Floral \& Yield characters, Cost Benefit ratio

Article Info

Accepted:

18 April 2020

Available Online:

10 May 2020
The experiment was carried out in the Forest Nursery and Research farm, Department of Agroforestry, Sam Higginbottom Institute of Agriculture, Technology and Sciences, Allahabad. The experiment was laid out in a Randomized Block Design ( $2 \times 4$ factorial) having eight treatments and three replications. The finding of the research revealed that floral characters were maximum in T7 (S4V1) [Tagetes erecta (antigua)] with spacing $35 \times 65 \mathrm{~cm}$ and yield parameter was maximum in T1 (S1V1) [Tagetes erecta (antigua)] with spacing $35 \times 35 \mathrm{~cm}$ and also advantage and return in terms of cost benefit ratio, treatment T1 (S1V1)[Tagetes erecta (antigua)] with spacing $35 \times 35 \mathrm{~cm}$ is best among all the treatments. Thus according to this experiment Tagetes erecta is better than Tagetes patula in most of the parameters under Subabul (Leucaena leucocephala) based Agroforestry system in Allahabad conditions.

\section{Introduction}

Agroforestry is an ancient land use practice of growing trees in association with crops. Trees play an important role in ecosystem in all terrestrials and provide a range of products and services to rural and urban people. As natural vegetation is cut for agriculture and other types of development, the benefits that trees provide are best sustained by integrating trees into agricultural system. The perennial woody plants provide direct and indirect benefits like food, fuel, fodder, fertilizer, fibre, timber, shade, oxygen, windbreak, harbour wild life and improve microclimate and agricultural crops provides staple food to people. Agroforestry in true sense has been realized as the need of hour. It does not confine to regional, geographical or agroclimatic boundaries. The term Agroforestry is 
now internationally used as an umbrella term for all the multiple land use system. Subabul (Leucaena leucocephala) is capable of growing in diversified agro climatic conditions of tropical region and it also fixes atmospheric nitrogen equivalent to one tone of ammonium sulphate per hectare per year assuming 1000 trees per hectare. It is widely regarded as one of the most versatile of all tropical multipurpose trees because of exceptionally high rates of growth, disease and pest resistance, the rapid decomposition of its foliage makes Subabul an excellent mulch (surface application) or green manure crop. Leucacena can also contribute to erosion control. Tagetes is a genus of annual or perennial, mostly herbaceous plants (family- Asteraceae), it was described as a genus by Carl Linnaeus in 1753. It deter some common insect pests, as well as nematodes hence often used in companion planting for tomato, eggplant, chili pepper, tobacco, and potato. Marigolds are highly useful for medicinal purposes such as headaches, toothache, swelling, and strengthening the heart. Tagetes contains ingredients that might help decrease swelling (inflammation) and spasms, calm the nerves, and reduce blood pressure. Marigold also had a number of uses for culinary purposes; in fact, the name 'pot Marigold' refers back to the tradition of adding Marigold to the cooking pot. Tagetes erecta (Variety-Antigua), the Mexican marigold, also called Aztec marigold and it has a naturally basal-branching, dwarf growth habit. It has dark-green foliage and golf ball sized, double blooms in true orange or bright, clear yellow. The plant grows up to $25-30 \mathrm{~cm}$ (10-12") high and spreads to $25-30 \mathrm{~cm}$ (1012 ") wide. It is planted as seed or as nurserygrown seedlings. The dark green ferny foliage has a distinctive aromatic smell. Tagetes patula a French marigold is with several naturalised populations around the world. In some climates it flowers from July to October. In its native habitat of the highlands of central Mexico, blooms are produced from September to killing frost. Achenes ripen and are shed within two weeks of the start of bloom. The heads contain mostly hermaphrodite (having both male and female organs) florets and are pollinated primarily by beetles in the wild, as well as by tachinid flies and other insects. The leaves of all species of marigold include oil glands. The oils are pungent.

\section{Materials and Methods}

The experimental was conducted at the research and nursery area of the Department of Agroforestry, Sam Higginbottom Institute of Agriculture, Technology and Sciences. (Formerly Allahabad Agricultural Institute) Allahabad (U.P) which is situated at an elevation of $90.85 \mathrm{~m}$ above the mean sea level, at $28.87^{\circ} \mathrm{N}$ latitude and $81.15^{\circ} \mathrm{E}$ longitude. During the winter months especially December and January, temperature drops down to as low as $3-5^{\circ} \mathrm{C}$, while in the summer temperature reaches above $45-48^{0} \mathrm{C}$. Hot scorching winds are a regular feature during the summer whereas there may be an occasional spell of frost during the winter. The annual rainfall is 1100 mm, mostly during the monsoon autumn.

The mechanical and chemical analysis of soil from the experimental Fields was done to examine the fertility status and mechanical composition of soil structure. The soil samples were collected randomly from experimental field with the help of soil augur from surface to $12-18 \mathrm{~cm}$ depth. The soil samples were air-dried finally powder and thoroughly mixed. Then a representative soil sample of $5 \mathrm{~g}$ was taken for each mechanical and chemical analysis. The experiment was laid out in Randomized Block Design $(2 \times 4$ factorial) with 8 treatments and 3 replications. The different treatments were allocated in each replication. The different treatments 
have 4 spacing (i.e. $35 \times 35 \mathrm{~cm}, 35 \times 45 \mathrm{~cm}$, $35 \times 55 \mathrm{~cm}$ and $35 \times 65 \mathrm{~cm}$ ) with 2 species of marigold [i.e. Tagetes erecta (antigua) and Tagetes patula (jafri)].

\section{Treatment combination}

$\mathrm{T} 1: \mathrm{S} 1+\mathrm{V} 1$

$\mathrm{T} 2: \mathrm{S} 1+\mathrm{V} 2$

T3: $\mathrm{S} 2+\mathrm{V} 1$

$\mathrm{T} 4: \mathrm{S} 2+\mathrm{V} 2$

T5: $\mathrm{S} 3+\mathrm{V} 1$

T6: $\mathrm{S} 3+\mathrm{V} 2$

$\mathrm{T} 7: \mathrm{S} 4+\mathrm{V} 1$

$\mathrm{T} 8: \mathrm{S} 4+\mathrm{V} 2$

WHERE,

$\mathrm{V} 1=$ Tagetes erecta (antigua)

$\mathrm{V} 2=$ Tagetes patula $($ jafri $)$

$\mathrm{S} 1=35 \times 35 \mathrm{~cm}$

$\mathrm{S} 2=35 \times 45 \mathrm{~cm}$

$\mathrm{S} 3=35 \times 55 \mathrm{~cm}$

$\mathrm{S} 4=35 \times 65 \mathrm{~cm}$

\section{Observations recorded}

\section{Plant parameters}

Number of days required for first flower bud emergence from transplanting

First flower bud appearance in each plant was noted soon after the flower buds were visible. To record the first flower bud appearance, the plants were observed critically and after emergence the buds are tagged. Days for flower bud appearance were calculated from transplanting date to flower bud appearance date.

\section{Number of flowers per plant}

Number of flowers harvested during the period of flowering was recorded and total number of flower calculated for all pickings.

\section{Diameter of flower head (cm)}

The diameter of fully opened flowers was measured and expressed in $\mathrm{cm}$.

\section{Flower yield (t/ha)}

The weight of flower produced was recorded from the first to last harvest per plot and flower yield per plot was calculated. The flower yield per hectare was calculated on the basis of yield per plot.

\section{Tree parameters}

\section{Height of tree (m)}

Height of the subabul tree was measured by measuring tape and expressed in meter (m). The average height of tree before transplantation is $1.10 \mathrm{~m}$ and after it is 1.72 $\mathrm{m}$.

\section{Collar diameter $(\mathbf{c m})$}

The average collar diameter of subabul before transplantation is $5.52 \mathrm{~cm}$ and after it is 5.56 $\mathrm{cm}$.

\section{Specific gravity}

Specific gravity of Subabul is $0.45-0.55$.

\section{Results and Discussion}

\section{Floral characters}

Number of days required for $1^{\text {st }}$ flower bud emergence from transplanting (days)

Data presented in Fig 1 highlights the significant influence of spacing on days taken to flower bud initiation while, species and interaction between spacing and species treatment was found non-significant. 
The maximum number of days taken to first flower bud initiation i.e. 42.3 days in (S1V1) Tagetes erecta (antigua) and 40.6 days in (S1V2) Tagetes patula (jafri) were found in closer spacing $35 \times 35 \mathrm{~cm}$ while, minimum number of days taken to first flower bud initiation i.e. 32.3 days in (S4V1) Tagetes erecta (antigua) and 30.7 days in (S4V2) Tagetes patula (jafri) were noted with wider spacing $35 \times 65 \mathrm{~cm}$. As in comparison of both the species maximum number of days taken to first flower bud initiation were found in Tagetes erecta (42.27) with spacing $35 \times 35$ $\mathrm{cm}$ and minimum number of days required for first flower initiation is in Tagetes patula (30.73) with spacing $35 \times 65 \mathrm{~cm}$, thus bud appear first in Tagetes patula than Tagetes erecta in all spacing.

\section{Number of flowers per plant}

Perusal of the data in Fig 2 revealed the significant influence of spacing, species and also influence of interaction between spacing and species is also significant in number of flowers per plant in Tagetes erecta and Tagetes patula under Leucaena leucocephala based Agroforestry system.

The maximum numbers of flowers were found is 36.8 in (S4V2)Tagetes patula (jafri) with spacing $35 \times 65 \mathrm{~cm}$, followed by 36.3 in (S3V2)Tagetes patula (jafri) with spacing 35 $\times 55 \mathrm{~cm}$. The flowers of Tagetes patula (jafri) was small in size and more in number than Tagetes erecta (antigua) in all the treatments. The minimum number of flowers were found is 23.5 in (S1V1)Tagetes erecta (antigua) with spacing $35 \times 35 \mathrm{~cm}$.

In all treatments of both species as the spacing increases the number of flowers increases, this might be due to less competition within the plants for light, nutrients, air, water, etc.

\section{Diameter of flower head $(\mathrm{cm})$}

Different spacing and species of marigold significantly influenced the diameter of flower head but the interaction between spacing and marigold species were nonsignificant in Tagetes erecta and Tagetes patula under Leucaena leucocephala based Agroforestry system.

The data pertaining to diameter of flower head (Fig 3) revealed that diameter of flower head were found to increase by increasing the spacing. The maximum diameter of flower head i.e. $9.7 \mathrm{~cm}$ were recorded in treatment S4 V1[Tagetes erecta (antigua)] with wider spacing $35 \times 65 \mathrm{~cm}$ followed by treatment S3V1 $(9.5 \mathrm{~cm})$ [Tagetes erecta (antigua)] with spacing $35 \times 55 \mathrm{~cm}$ while minimum diameter of flower head were recorded in treatment S1V2 $(3.1 \mathrm{~cm})$ [Tagetes patula (jafri)] with spacing $35 \times 35 \mathrm{~cm}$. The flower size of Tagetes erecta is more than Tagetes patula so diameter of flower head of Tagetes erecta is more than Tagetes patula in all the treatments.

\section{Yield character}

\section{Flower yield (t/ha)}

Spacing, species and interaction between spacing and species significantly influenced the flower yield (t/ha) in Tagetes erecta and Tagetes patula under Leucaena leucocephala based Agroforestry system. The data in Fig 4 clearly indicated that the flower yield per plot decreased significantly with increase in the planting distance. Significantly maximum flower yield per plot i.e. 12.0 t/ha in S1V1 [Tagetes erecta (antigua)] with closer spacing $35 \times 35 \mathrm{~cm}$ followed by treatment S2V1 (11.9 t/ha) [Tagetes erecta (antigua)] with spacing $35 \times 45 \mathrm{~cm}$ while minimum flower yield per plot were recorded in treatment S4V2 (6.3 t/ha) [Tagetes patula (jafri)] with spacing 35 $\times 65 \mathrm{~cm}$ (Table 1 and 2). 
Figure.1 Effect of spacing on number of days required for 1st flower bud emergence from transplanting of Tagetes erecta and Tagetes patula under Subabul (Leucaena leucocephala) based Agroforestry system

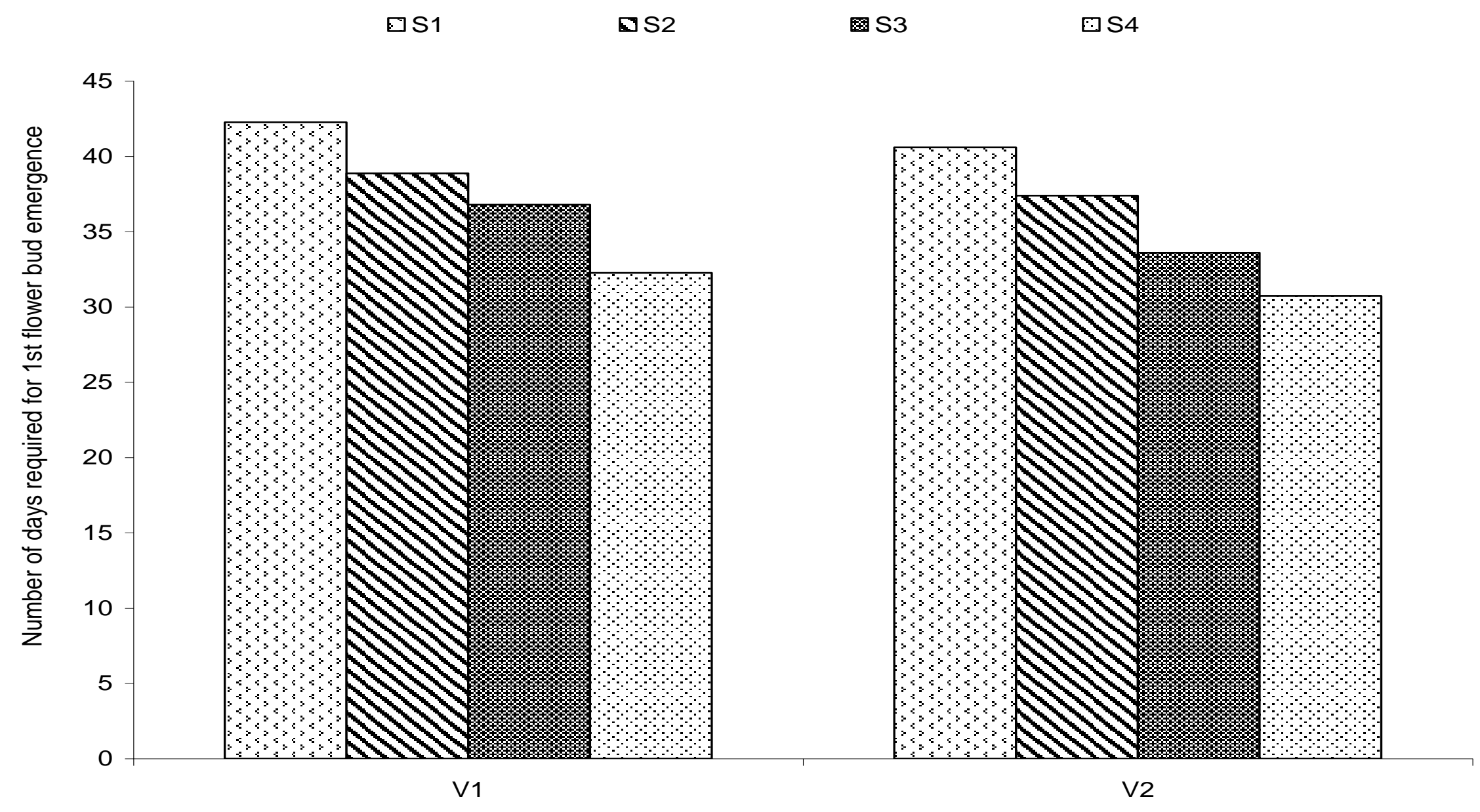


Figure.2 Effect of spacing on number of flowers per plant of Tagetes erecta and Tagetes patula under Subabul (Leucaena leucocephala) based Agroforestry system

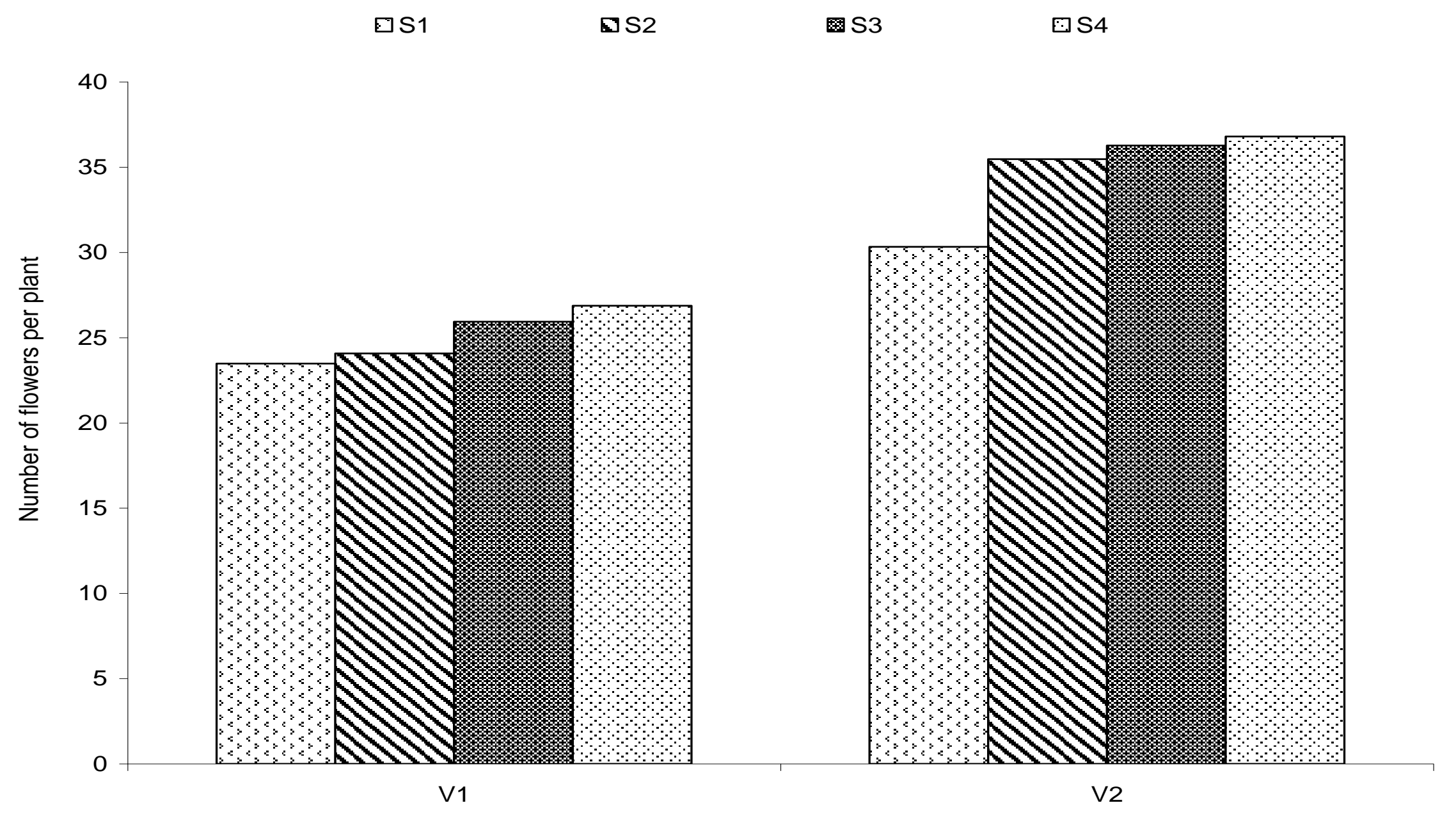


Figure.3 Effect of spacing on diameter of flower head $(\mathrm{cm})$ of Tagetes erecta and Tagetes patula under Subabul (Leucaena leucocephala) Based Agroforestry system

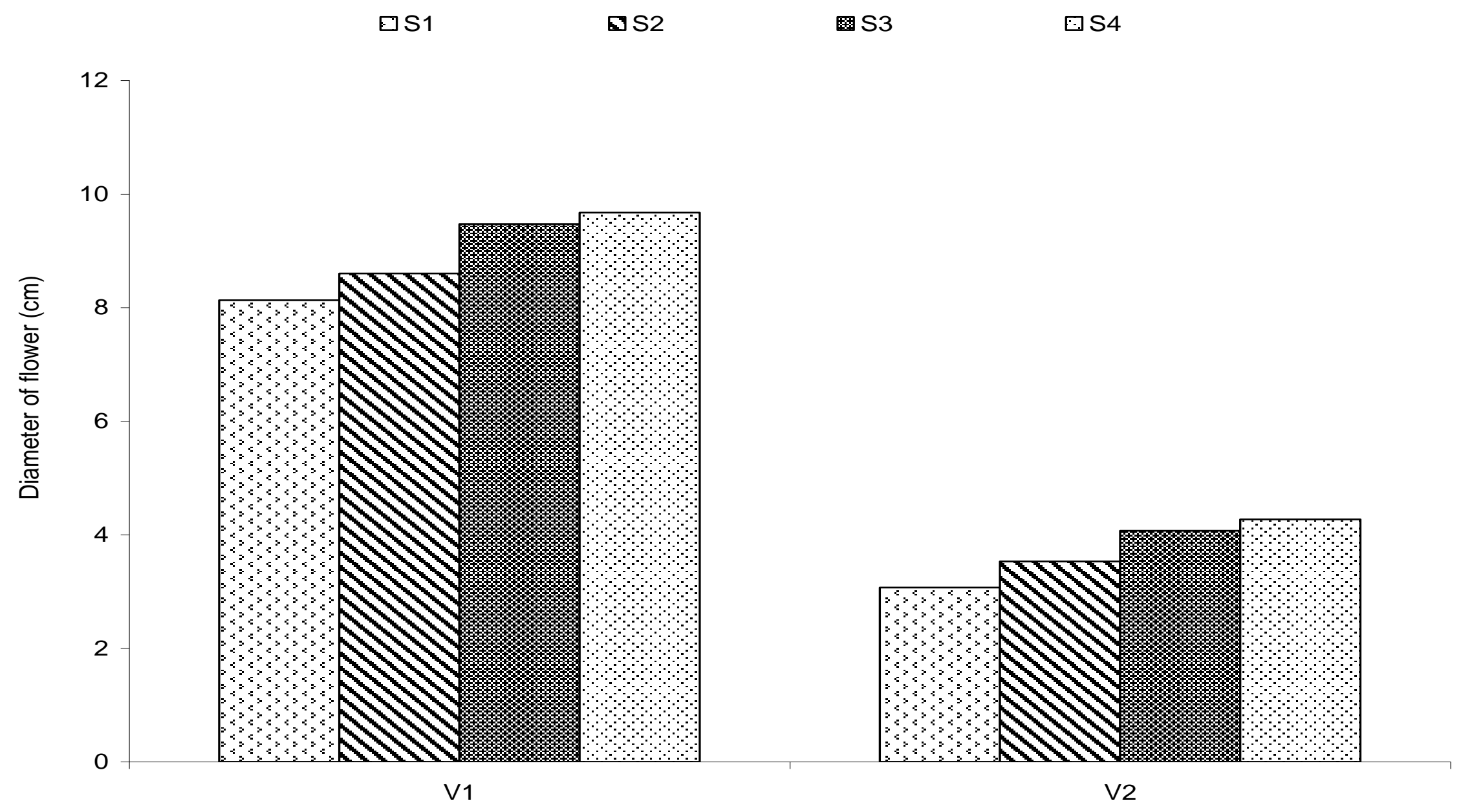


Figure.4 Effect of spacing on flower yield (t/ha) of Tagetes erecta and Tagetes patula under Subabul (Leucaena leucocephala) Based Agroforestry system
$\boxminus S 1$
$\mathbf{\nabla S 2}$
图 S3
Đ4

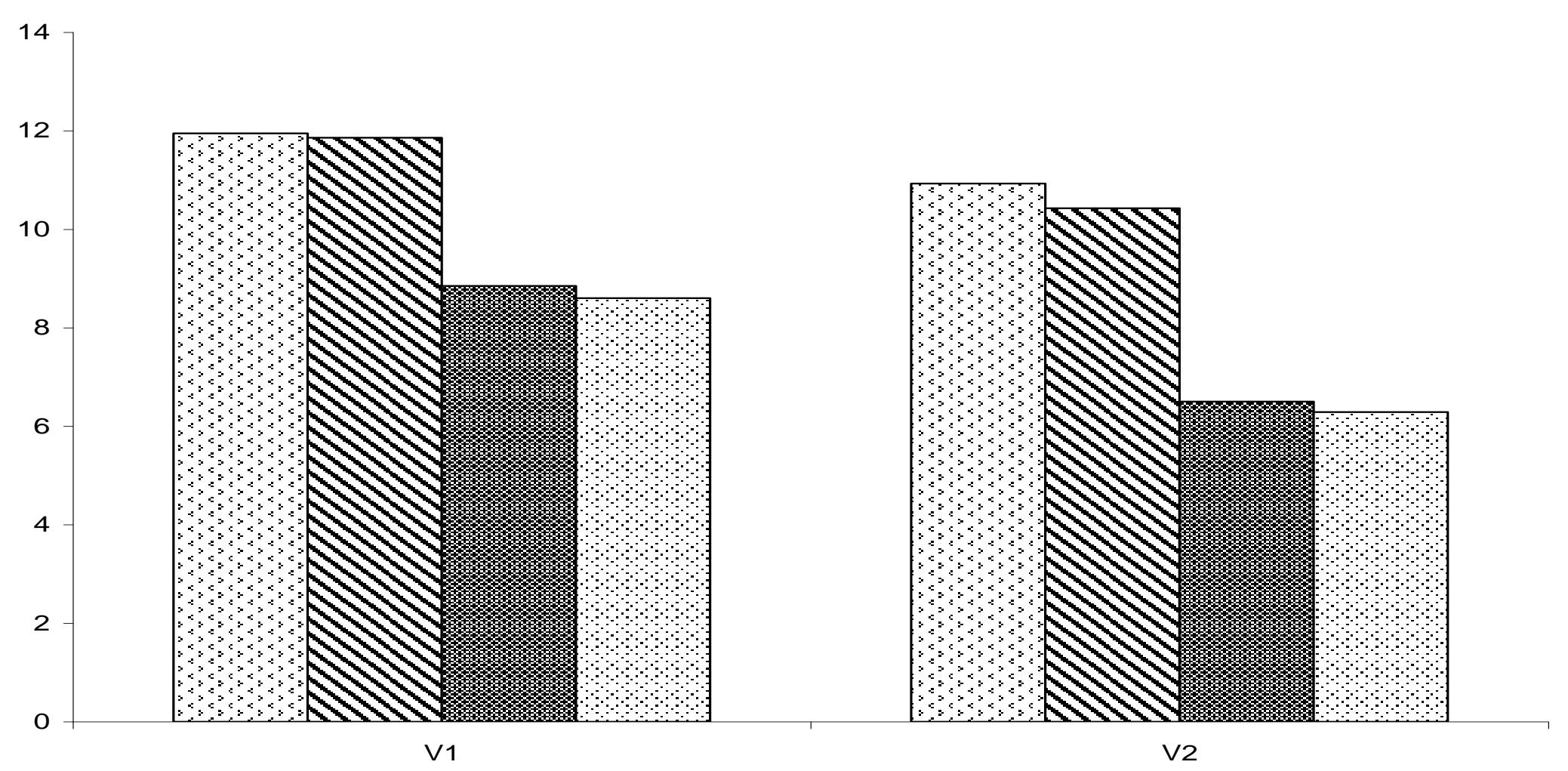


Economic Analysis

Table.1 Fixed cost of cultivation of Tagetes erecta and Tagetes patula under Subabul (Leucaena leucocephala) based Agroforestry system

\begin{tabular}{|c|c|c|c|c|c|}
\hline S.No. & Particulars & Unit & Qty. & Rate/unit(Rs) & $\operatorname{Cost}(\operatorname{Rs} /$ ha $)$ \\
\hline A. & Land preparation & & & & \\
\hline 1 & Ploughing with M.B plough & Hrs & 4 & 500 & 2000 \\
\hline 2 & Disc Harrow & Hrs & 4 & 500 & 2000 \\
\hline 3 & Planking and leveling & Hrs & 2 & 400 & 800 \\
\hline 4 & Layout of the field & Labour & 25 & 200 & 5000 \\
\hline B. & Seed and transplantation & & & & \\
\hline 1 & Cost of seed & Kg & 1.5 & 6000 & 9000 \\
\hline 2 & Transplantation & Labour & 20 & 200 & 4000 \\
\hline C. & After care & & & & \\
\hline 1 & Gap filling & Labour & 8 & 200 & 1600 \\
\hline 2 & Weeding(5 weeding 4 labour) & Labour & 20 & 200 & 4000 \\
\hline D. & Irrigation & & & & \\
\hline 1 & Tubewell [5 irri.(2hr/irri)] & Hrs & 10 & 300 & 3000 \\
\hline 2 & Labour for irrigation & Labour & 20 & 200 & 4000 \\
\hline E. & $\begin{array}{c}\text { Picking and other operation (6 } \\
\text { labour for } 5 \text { days) }\end{array}$ & Labour & 30 & 200 & 6000 \\
\hline F. & Pruning of Subabul & Labour & 25 & 200 & 5000 \\
\hline G. & Transportation charges & & & & 4000 \\
\hline H. & $\begin{array}{c}\text { Supervision \& imputed value } \\
\text { of family labour }\end{array}$ & Months & 3 & 3000 & $9000+1200$ \\
\hline I. & Rental value on land & Months & 3 & 600 & 1800 \\
\hline $\mathbf{J}$. & Interest on fixed cost (12.5\%) & & & & 1200 \\
\hline $\mathbf{K}$. & Insurance charges & & & & 1850 \\
\hline \multirow[t]{2}{*}{ L. } & $\begin{array}{c}\text { Interest on working capital } \\
(9.5 \%)\end{array}$ & & & & 4047 \\
\hline & Total fixed cost & & & & 69497 \\
\hline
\end{tabular}


Table.2 Cost Benefit Ratio of Tagetes erecta, Tagetes patula and Subabul (Leucaena leucocephala) in Agroforestry system

\begin{tabular}{|c|c|c|c|c|c|c|c|c|c|c|}
\hline Treatment & $\begin{array}{l}\text { Yield of } \\
\text { Marigold } \\
\text { flowers } \\
\text { (t/ha) }\end{array}$ & $\begin{array}{c}\text { Rate of } \\
\text { flowers @ } \\
\text { Rs/tone }\end{array}$ & $\begin{array}{l}\text { Total } \\
\text { Amount } \\
\text { of } \\
\text { flowers } \\
\text { (Rs) }\end{array}$ & $\begin{array}{c}\text { Yield of } \\
\text { Subabul } \\
\text { (fuelwood) } \\
\text { (t/ha) }\end{array}$ & $\begin{array}{c}\text { Rate of } \\
\text { fuelwood@ } \\
\text { Rs/tone }\end{array}$ & $\begin{array}{c}\text { Total } \\
\text { Amount of } \\
\text { fuelwood } \\
\text { (Rs) }\end{array}$ & $\begin{array}{l}\text { Gross } \\
\text { Return } \\
\text { (Rs/ha) }\end{array}$ & $\begin{array}{l}\text { Total cost of } \\
\text { cultivation } \\
(\mathrm{Rs} / \mathrm{ha})\end{array}$ & $\begin{array}{l}\text { Net profit } \\
\text { (Rs/ha) }\end{array}$ & $\begin{array}{c}\text { Cost } \\
\text { benefit } \\
\text { ratio } \\
\text { (C:B) }\end{array}$ \\
\hline T1 & 11.95 & 18000 & 215100 & 8.648 & 4000 & 34592 & 249692 & 69497 & 180195 & 3.59 \\
\hline $\mathbf{T} 2$ & 10.93 & 10000 & 109300 & 8.648 & 4000 & 34592 & 143892 & 69497 & 74395 & 2.07 \\
\hline T3 & 11.85 & 18000 & 213300 & 8.648 & 4000 & 34592 & 247892 & 69497 & 178395 & 3.56 \\
\hline T4 & 10.43 & 10000 & 104300 & 8.648 & 4000 & 34592 & 138892 & 69497 & 69395 & 1.99 \\
\hline T5 & 8.85 & 18000 & 159300 & 8.648 & 4000 & 34592 & 193892 & 69497 & 124395 & 2.78 \\
\hline T6 & 6.50 & 10000 & 65000 & 8.648 & 4000 & 34592 & 99592 & 69497 & 30095 & 1.43 \\
\hline T7 & 8.60 & 18000 & 154800 & 8.648 & 4000 & 34592 & 189392 & 69497 & 119895 & 2.72 \\
\hline T8 & 6.29 & 10000 & 62900 & 8.648 & 4000 & 34592 & 97492 & 69497 & 27995 & 1.40 \\
\hline
\end{tabular}


It is concluded from the experiment that most of the floral characters were maximum in Tagetes erecta (antigua) with spacing $35 \times 65$ $\mathrm{cm}$ (S4V1) and yield parameter was maximum in Tagetes erecta (antigua) with spacing $35 \times 35 \mathrm{~cm}(\mathrm{~S} 1 \mathrm{~V} 1)$. Thus according to this experiment Tagetes erecta is better than Tagetes patula in most of the parameters .However based on advantage and return in terms of cost benefit ratio, Tagetes erecta with spacing $35 \times 35 \mathrm{~cm}$ is best among all the treatments under Subabul (Leucaena leucocephala) based Agroforestry system.

\section{References}

Anju Pal et al., (2007) Effect of plant spacing on growth and flowering in African marigold (Tagetes erecta L.) under Budnelkhand Region. Progressive Research, 2:70-72

Chaturvedi, S. K. et al., (2010) Effect of spacing and nitrogen level on growth, flowering and yield of marigold (Tagetes erecta L.) cv pusanarangi. Environment and Ecology, 28:15671570

Chundauat. A. K. A text book of agroforestry chapter introduction.

Ghosh,P. et al., (2008) Performance of Tagetes erecta Linn.cv. 'Siracole" as influenced by planting time and spacing under West Bengal conditions. Natural Product Radiance, 7: 437-443

Ravneet Kour et al., (2012) Effect of spacing and pinching on flower production in marigold cv. Pusa Narangi Gainda in mid-hills of J\&K state. Asian Journal of Horticulture, 7(2):307-309

Srivastava, S. K. et al., (2002) Effect of spacing and pinching on growth and flowering of 'Pusa Narangi Gainda' marigold (Tagetes erecta). Indian Journal of Agricultural Sciences, 72(10):611-612

Sunitha, H. M. et al., (2007) Effect of plant spacing and integrated nutrient management on yield and quality of seed and vegetative growth parameters in African marigold (Tagetes erecta Linn.). Journal of Ornamental Horticulture, 10(4):245-249

Sonali Deshmane et al., (2012) Effect of planting time and spacing on quality and yield of French marigold. Journal of Soils and Crops, 22(1):172-176

Tiwari, R. K. et al., (2010) Influence of spacing and nitrogen on growth and yield of marigold (Tagetes erecta L.) cv Pusa Narangi. Horticultural Journal; 23(1):26-29.

\section{How to cite this article:}

Swati Suchi. 2020. Effect of Spacing on Growth Attributes and Socio-economic Benefits of Marigold (Tagetes species) under Subabul (Leucaena leucocephala) based Agroforestry System. Int.J.Curr.Microbiol.App.Sci. 9(05): 2288-2298.

doi: https://doi.org/10.20546/ijcmas.2020.905.261 